\section{Muzeum-cmentarz. Kilka uwag o (infra)strukturalnej przemocy}

Zuzanna Dziuban

TEKSTY DRUGIE 2020, NR 4, S. 67-85

DOI: $10.18318 /$ td.2020.4.5 | ORCID: 0000-0002-3410-6714

\section{No Exit}

Kiedy myślę o Polskich muzeach historycznych poświęconych Zagładzie, lubię wracać do pracy Jochena Gerza Exit. Projekt Dachau. Lubię, ponieważ proponuje on krytyczne, głęboko polityczne spojrzenie na współczesne muzea i miejsca pamięci ustanowione na terenach byłych nazistowskich obozów ${ }^{1}$. Exit to przestrzenna instalacja, którą niemiecki artysta pokazał w Sammlung

1 Za Chantal Mouffe przyjmuję tu szerokie (ontologiczne) rozumienie polityczności jako "sposobu, w jaki stanowione jest społeczeństwo", poprzedzające, ale też porządkowane i artykułowane przez praktyki konwencjonalnej polityki. Według Mouffe polityczność to "wymiar antagonistyczny społeczeństwa" będący formą organizacji władzy, ustanawiania relacji międzyludzkich, form podmiotowości i ich społecznej hierarchizacji. Polityczność to także, jak argumentuje w tekście, analityczna perspektywa, która kładzie nacisk na odsłanianie i krytyczną interpretację relacji władzy oraz praktyk dyscyplinowania, otheringu, wykluczenia i upodmiotowienia/odpodmiotowienia, wpisanych w społeczne życie i normatywne społeczne przestrzenie. Ch. Mouffe Polityczność, Wydawnictwo Krytyki Politycznej, Warszawa 2008, s. 23,24 .
Tekst powstał w ramach projektu Globalized Memorial Museums, sfinansowanego przez European Research Council (ERC), ze środków ramowego programu Horizon 2020 (GMM - grant nr 816784).

\section{Zuzanna Dziuban -}

dr, badaczka w Instytucie Kulturoznawstwa i Historii Teatru Austriackiej Akademii Nauk, projekt ERC Globalised Memorial Museums. Autorka książki Obcość, bezdomność, utrata.Wymiary atopii współczesnego doświadczenia kulturowego (2009) i redaktorka tomu Mapping the 'forensic turn'. Engagements with materialities of mass death in Holocaust studies (2017). Zajmuje się przemocą polityczną, pamięcią i przestrzenią, oraz polityką martwych ciał. Kontakt: zuzanna.dziuban@oeaw. ac.at. 
Kunstmuseum w Bochum w 1972 roku. Na dwudziestu szkolnych ławkach, ustawionych w dwóch równych rzędach i oświetlonych światłem nagich żarówek, Gerz umieścił 20 identycznych albumów fotograficznych. Albumy wypełnione są zdjęciami, które zrobił podczas wizyty na terenie byłego obozu koncentracyjnego w Dachau. Dokumentują one przestrzeń miejsca pamięci przez pryzmat tablic informacyjnych regulujących zachowanie i narzucających zwiedzającym konkretne przestrzenne praktyki. Album rozpoczyna się zdjęciem znaku wyjścia, subtelnie ustanawiającego ramę interpretacyjną pracy; pokazuje następnie przepisy obowiązujące w muzeum i miejscu pamięci, szczegółowe informacje na temat jego funkcjonowania oraz zakazów nałożonych na osoby poruszające się po przestrzeni byłego obozu: zakaz palenia, zakaz wprowadzania/wyprowadzania psów, zakaz wejścia z wózkiem dziecięcym, zakaz śmiecenia, zakaz opuszczania wyznaczonego szlaku, zakaz pisania na ścianach, zakaz dotykania eksponatów muzealnych, zakaz wejścia, zakaz wyjścia. Instalacja Gerza nie stanowi zatem artystycznego przepracowania pamięci wydarzeń, które zostały kilka dekad po wojnie upamiętnione w Dachau. Skupia się ona raczej na infrastrukturze muzeum i doświadczeniu zwiedzających starannie dyscyplinowanym przez przestrzenną i dyskursywną organizację miejsca pamięci.

W 2011 roku instalacja Gerza została pokazana w Polsce, w krakowskim Muzeum Sztuki Współczesnej. Takjak w Niemczech, także w polskim odbiorze, zramowana została jako "polemika z koncepcją muzeum historycznego"2. Odczytano tę pracę jako krytykę „wizualnej legislatury”3 i dyscyplinującego wymiaru muzeów-miejsc pamięci poświęconych Zagładzie, sprowadzającą zdaniem niektórych tę koncepcję ad absurdum ${ }^{4}$. Moim zdaniem nie ma nic $\mathrm{z}$ absurdu w pracy Gerza. Jej znaczenia nie mogą również zostać zredukowane do tego, że odsłania i krytycznie podejmuje ona „mechanizmy nadzoru w pozornie bezpiecznej przestrzeni"5 - nie tylko dlatego że pozorne

2 Praca została pokazana w ramach wystawy Historia w sztuce. D. Jarecka Muzeum bolesnych pytań, "Gazeta Wyborcza" 2011, https://wyborcza.pl/1,76842,9622673,Muzeum_bolesnych_ pytan.html (10.03.2020).

3 J. Gerz Bemerkungen zu Exit, w: Exit. Das Dachau-Projekt, Hrsg. von J. Gerz, F. Levy, Frankfurt am Main, Verlag Roter Stern 1978, s. 137.

4 H. Bredekamp Akty Obrazu jako świadectwo i werdykt, w: Historia wizualna. Obrazy w dyskursach niemieckich historyków, red. M. Saryusz-Wolska, Scholar, Warszawa 2020, s. 208.

5 J. Chludzińska MOCAK - Nowe oblicze sztuki, „Zwierciadło” 2011, https://zwierciadlo.pl/kultura/ sztuka/mocak-nowe-oblicze-sztuki (10.03.2020). 
bezpieczeństwo, zarówno epistemologiczne, jak i ontologiczne niekoniecznie stanowi zasadę porządkującą narrację i doświadczenie muzeów ustanowionych na terenie byłych obozów koncentracyjnych i zagłady. Instalacja Gerza sięga głębiej, tematyzując bardziej podstawowy paradoks wpisany w strukturę (i infrastrukturę) instytucji, której celem jest upamiętnienie zbrodni popełnionej w Dachau przez Nazistów. Wybierając na potrzeby projektu muzeum in situ, a więc historyczne miejsce zbrodni, oraz zestawiając funkcjonalność zakazów i nakazów rządzących doświadczeniem obozu koncentracyjnego i muzeum Dachau, Gerz chciał odsłonić strukturalną ciągłość łączącą zabójczy reżim obozu z dyscyplinującym reżimem muzeum. „Dyskursywna organizacja obozu koncentracyjnego Dachau tylko pozornie stoi w sprzeczności z dyskursywną organizacją muzeum Dachau; jest odwrotnie, obie wzajemnie się uzupełniają, stanowią swoje przedłużenie, jedna jest projektem drugiej"6, zauważył. Przemoc przenika i organizuje oba rodzaje przestrzeni.

W projekcie niemieckiego artysty ta wzajemna implikacja dwóch instytucji, obozu i muzeum na terenie byłego obozu - bez wątpienia odgrywających radykalnie odmienne polityczne i kulturowe role - nie tylko podważa pozorną niewinność miejsca pamięci, ale także obnaża dyskretne, acz nieustępliwe trwanie strukturalnej logiki nazistowskich obozów w „, codziennym funkcjonowaniu administracji, instytucji rządowych i muzeów"7. Gerzowi nie chodzi jednak jedynie o ciągłości pewnych aspektów nazizmu w niemieckiej powojennej polityce, prawie i kulturze. Exit mógłby być czytany przecież także jako artystyczna antycypacja Agambenowskiej idei obozu jako biopolitycznego paradygmatu nowoczesności ${ }^{8}$. Exit przypomina, że muzea-miejsca pamięci, jako struktury wykluczenia i narzędzia dyscyplinujące, biorą udział w produkcji podmiotowości już nie w czasie Zagłady, ale późnego kapitalizmu. Pracę Gerza interpretować można także, i w tym kierunku zmierza moja analiza, przez pryzmat kategorii kontinuum przemocy zaproponowanej przez Nancy Scheper-Hughes i Philippe'a Bourgois?. W ich antropologicznej perspektywie przemoc przybiera różne formy, nieredukowalna jest do bezpośredniej przemocy fizycznej i myślana jest raczej

6 J. Gerz Bemerkungen zu Exit, s. 137.

7 J. Gerz, F. Levy Exit. Das Dachau-Projekt, Frankfurt am Main, Verlag Roter Stern 1978, s. 147.

8 G. Agamben Co zostaje z Auschwitz. Archiwum i świadek, przeł. S. Królak, Sic!, Warszawa 2008.

9 N. Scheper-Hughes, P. Bourgois Introduction. Making sense of violence, w: Violence in War and Peace, ed. by N. Scheper-Hughes, P. Bourgois, Blackwell, Malden-Oxford-Carlton 2004. 
z poziomu kulturowego i społecznego. W tym ujęciu „przemoc czasów wojny” niekiedy płynnie przechodzi w „przemoc czasów pokoju”.To przejście nie jest oczywiście w pełni płynne. Stanowi raczej złożony proces, w którym przemoc osłabia swoje ostrze, staje się (dla niektórych) mniej oczywista i odczuwalna. To proces, w ramach którego przemoc zostaje ulokowana w symbolicznych i społecznych strukturach i normatywnych przestrzeniach społecznych, przez co zostaje znaturalizowana i tym samym staje się często niewidzialna jako przemoc. Artykulację znajduje w hierarchiach i normach społecznych oraz w normatywnych kategoriach podmiotów będących przedmiotem włączenia lub, odwrotnie, będących przedmiotem otheringu, dehumanizacji i wykluczenia. Tak niewidzialna/uniewidzialniona przemoc to przemoc strukturalna ${ }^{10}$, która materializuje się w codziennym funkcjonowaniu administracji, instytucji rządowych, w infrastrukturze miejsc pamięci i muzeów.

Nie chodzi tu oczywiście o kreślenie fałszywych analogii między obozową rzeczywistością a sytuacją osób zwiedzających miejsce pamięci, pozbawionych możliwości zapalenia papierosa lub zejścia z wyznaczonego traktu. Gerz zwraca raczej uwagę na produktywność przestrzeni będącej locus przemocy, zarówno tej bezpośredniej, fizycznej, jak i strukturalnej, oraz na (nie)ciagłość i strukturalną obecność przemocy tam, gdzie jej pozornie nie ma. Kiedy wracam do projektu Exit, myśląc o polskich muzeach in situ poświęconych Zagładzie, to jednak nie zwiedzający i ich doświadczenie są w centrum mojej uwagi - jest nim przestrzeń zdefiniowana przez obecność ludzkich szczątków. W tekście argumentować będę, że także o nich można myśleć w kategoriach podmiotowości, w których wytwarzaniu bierze udział przestrzenna organizacja miejsc po byłych obozach. Analizując powojenną historię miejsc pamięci i rozwijające się wokół nich praktyki i infrastrukturalne transformacje, pokażę, jak ich funkcjonowanie wpisuje się w kontinuum przemocy dotykającej ofiary obozu, które, także po śmierci, są przedmiotem procesów upodmiotowiania/ odpodmiotowania, dehumanizacji i wykluczenia. Postaram się tu również odpowiedzieć na pytanie, za pomocą jakich pojęć i perspektyw teoretycznych można w pole widzenia wprowadzić niewidzialną/uniewidzialnianą przemoc, wpisaną w (infra)strukturę przestrzeni, w których leżą ludzkie szczątki.

W polskich badaniach nad miejscami Zagłady obecność ludzkich szczątków przełożyła się na dwie dominujące perspektywy teoretyczne zorganizowane wokół kategorii traumy i natury. Pierwsza z nich stabilizuje (jeśli nie

10 Kategorię przemocy strukturalnej upowszechnił na gruncie antropologii Paul Farmer. P. Farmer An anthropology of structural violence, "Current Anthropology" 2004 No. 45 (3). 
esencjalizuje) znaczenie byłych obozów zagłady jako przestrzeni niedającej się przepracować śmierci: stają się one „autentycznymi krajobrazami traumatycznymi"11 lub „miejscami strukturalnie naznaczonymi traumą"12. Druga perspektywa uwypukla znaczenie materialnej obecności i materialnych transformacji szczątków, wpisanych w dynamikę natury-kultury. Postantropocentryczna, środowiskowa historia Zagłady, bo to tę perspektywę mam na myśli, konceptualnie odzyskuje procesualność miejsc, w których wydarzyła się Zagłada, rozumianych tu jako złożone ekosystemy, jako sieci ludzkich i nieludzkich aktorów (ziemi, zwierząt, roślin, powietrza, wody) ${ }^{13}$. Stawia ona pytania o wpływ obecności szczątków ludzkich - „postludzkiego” organicznego i nieorganicznego materiału - na środowisko i odwrotnie. Miejsca po byłych obozach stają się w tym ujęciu dynamicznym, wielogatunkowym archiwum, materialnym świadectwem Zagłady.

Jeśli pierwsza z tych perspektyw, zorganizowana wokół kategorii traumy, nie przekonuje mnie ze względu na swój odpolityczniający esencjalizm i problematyczne - w kontekście polskich muzeów Zagłady - zastosowania tej kategoriii ${ }^{14}$, druga, choć dużo mi bliższa, wydaje mi się niewystarczająca jako narzędzie analityczne do badania (i uwidzialniania) form przemocy wpisanych w polskie miejsca pamięci poświęcone Zagładzie. Wprowadzając szczątki ludzkie w porządek natury (i konstruując je jako postludzkie), do pewnego stopnia poznawczo zaciera ich ciągłą obecność w porządku politycznym jako podatne na przemoc formy podmiotowości.

Dlatego zamiast pisać o terenach po byłych obozach jako przestrzeniach traumy czy złożonych ekosystemach, za Tomaszem Kranzem - z krytycznym dystansem - ujmować je będę tu jako „muzea-cmentarze"15. Wprowadzając kategorię muzeum-cmentarza, Kranz podkreślił rolę miejsc pamięci ustanowionych na terenie byłych obozów zagłady jako historycznych przestrzeni pełniących

11 M. Fabiszak, M. Owiński Wstęp, w: Obóz-muzeum. Trauma we współczesnym wystawiennictwie, red. M. Fabiszak, M. Owiński, Universitas, Kraków 2013, s. 7.

E. Domańska Recenzja wydawnicza, w: Obóz-muzeum..., okładka.

Odsyłam tu do tekstów Ewy Domańskiej, Mikołaja Smykowskiego, Jacka Małczyńskiego, Romy Sendyki, Aleksandry Ubertowskiej i Agnieszki Kłos zebranych w specjalnym numerze „Tekstów Drugich" 2017 nr 2: Środowiskowa historia Zagłady.

Krytykę kategorii traumy w kontekście polskiej pamięci o Zagładzie proponuje Elżbieta Janicka. E. Janicka Pamięć przyswojona. Koncepcja polskiego doświadczenia zagłady Żydów jako traumy zbiorowej w świetle rewizji kategorii świadka , "Studia Litteraria et Historica” 2014-2015 nr 3/4. 
funkcję „rzeczywistych i symbolicznych cmentarzy”16. Z mojej perspektywy muzeum-cmentarz to równocześnie pojęcie (kategoria analityczna), praktyka i dynamiczna kulturowa/polityczna przestrzeń, która wytwarza/unieważnia znajdujące się w jej ramach martwe podmioty. W zaproponowanym tu ujęciu muzeum-cmentarz to zmienna, ale nieodmiennie (politycznie) produktywna „infrastruktura” będąca materialną artykulacją hierarchii i norm społecznych

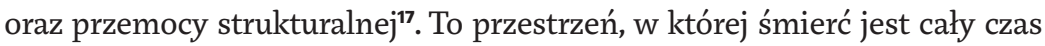
symbolicznie i materialnie przepracowywana. Jest ona do gruntu (dosłownie i w przenośni) polityczna i zajmuje istotne miejsce w kontinuum przemocy. To kontinuum nie jest tu rozumiane przeze mnie, oczywiście, jako nieustępliwe trwanie strukturalnej logiki nazistowskich obozów. Chodzi tu raczej o ciagłość dynamiki otheringu, wykluczenia i przemocy, która zarówno przed Zagładą, w jej trakcie i po wojnie, dotykała Żydów w Polsce - pozbawianych równego dostępu do praw, społecznych zasobów, przestrzeni (uniwersytetów, administracji państwowej czy armii), poddawanych bezpośredniej i zapośredniczonej dyskryminacji oraz fizycznej, ekonomicznej i symbolicznej przemocy ${ }^{18}$. Przemoc ta, jak argumentuję w tym tekście, znalazła przestrzenną i materialną realizację także w muzeach-cmentarzach na terenach byłych obozów zagłady, w formie nekroprzemocy: przemocy wobec ludzkich szczątków.

\section{Nekroprzemoc i zaniechanie/porzucenie}

Przyznanie przemocy wobec martwych ciał statusu przemocy wiązać można z obecnymi od lat 70. dyskusjami wokół repatriacji szczątków ludzkich zrabowanych podczas kolonizacji i pokazywanych w muzeach i antropologicznych kolekcjach zachodniej hemisfery ${ }^{19}$. Przyczynił się do tego także ogromny wzrost znaczenia materialnych praktyk wokół martwych ciał - poszukiwanych, ekshumowanych i identyfikowanych po różnych współczesnych

16 Tamże, s. 53.

17 Pojęcia infrastruktury i przemocy infrastrukturalnej rozumiem za Dennisem Rogersem i Brucem O'Neillem. D. Rogers, B. O'Neill Infrastructural violence. Introduction to the special issue, "Ethnography" 2012 No. 13 (4).

Zamiast długiej listy publikacji przywołam tu jedną, moim zdaniem wyjątkowo przekonującą, pozycję: K. Matyjaszek Produkcja przestrzeni żydowskiej w dawnej i współczesnej Polsce, Universitas, Kraków 2019.

19 D. Mihesuah Repatriation Reader. Who Owns American Indian Remains?, University of Nebraska Press, Lincoln 2000. 
epizodach politycznej przemocy - rekonfigurujący te praktyki w kategoriach troski o zmarłych ${ }^{20}$. Przemoc, której ciała poddawane są przez sprawców, stanowi jej antytezę. Ukrywanie zwłok, grzebanie ich w nieoznakowanych masowych grobach, pozostawanie niepogrzebanych, okaleczanie, niszczenie (np. przez kremację), okradanie lub kolekcjonowanie fragmentów zwłok to artykulacja pośmiertnego uprzedmiotowienia i dehumanizacji. Tak doświadczane są one przez rodziny ofiar, przez dotknięte przemocą społeczności, tak też często ramowane są przez prawo ${ }^{21}$. W porządku teoretycznym asumpt do (re)konceptualizacji tej modalności przemocy dały badania nad politykami martwych cial ${ }^{22}$, nekropolityką ${ }^{23}$ i necrogovernmentality ${ }^{24}$. Perspektywy te pokazują, w jakim stopniu nie tylko żywe ciała, ale także ciała zmarłych stają się przedmiotem suwerennej władzy, zarządzania, upolityczniania i odpolityczniania, włączana do prawno-politycznej wspólnoty i wyłączania z niej za sprawą różnych materialnych i społecznych praktyk. Rozciągnięcie działania władzy i suwerenności na rzeczywistość śmierci ustanawia martwe ciała jako podmioty polityczne.

W tak zdefiniowanym polu mogła pojawić się kategoria nekroprzemocy jako politycznie i kulturowo nacechowanej przemocy post mortem. Pożyczam tę kategorię od Jasona de Leóna, który wprowadza ją w książce The Land of Open Graves opowiadającej o życiu i śmierci w krajobrazie granicznym między Meksykiem i Stanami Zjednoczonymi. Nekroprzemoc w rozumieniu de Leóna to "przemoc popełniana i produkowana poprzez specyficzne sposoby obchodzenia się ze zwłokami, które są uznane za obraźliwe, świętokradcze lub nieludzkie [inhuman] przez sprawców, przez ofiarę (i jej/jego grupę kulturową), lub obie kategorie osób"25. De León zwraca uwagę na religijne - obowiązujące

20 Zob. np. A. Rosenblatt Digging for the Disappeared. Forensic Science after Atrocity, Stanford University Press, Stanford 2015.

21 Zarówno w przedwojennym, jak i powojennym polskim prawie bezczeszczenie szczątków ludzkich i grobów było objęte sankcjami karnymi.

22 K. Verdery The Political Life of Dead Bodies. Reburial and Postsocialist Change, Columbia University Press, New York 1999.

23 F. Ferrándiz, A.C.G.M. Robben Necropolitics. Mass Graves and Exhumations in the Age of Human Rights, Pennsylvania University Press, Philadelphia 2015.

24 I. Rojas-Perez Mourning Remains. State Atrocity, Exhumations, and Governing Disappeared in Peru's Postwar Andes, Stanford University Press, Stanford 2017.

25 J. de León The Land of Open Graves. Living and Dying on the Migrant Trail, University of California Press, Oakland 2015, 69. 
w większości kultur - podłoże swojej konceptualizacji. Wspomnę tu o tych zagadnieniach, które mogą mieć znaczenie dla chrześcijan i wyznawczyń judaizmu: nekroprzemoc uniemożliwia zgodne z religijnymi wytycznymi postępowanie ze szczątkami zarówno rodzinie jak i społeczności, do której należała zmarła osoba (godny pogrzeb, oznaczenie miejsca pochówku, możliwość odwiedzania zmarłych na cmentarzu), uderza także w reguły określające warunki godnego życia po śmierci (bycie przyjętym/przyjętą do „królestwa niebieskiego", wskrzeszenia po sądzie ostatecznym). Fizyczna integralność zwłok i nienaruszalność miejsca pochówku, także wtedy, gdy jest to dół zsypowy, do którego naziści wrzucali skremowane ludzkie szczątki, miejsce ukrycia szczątków czy masowy grób, odgrywa bardzo istotną rolę w żydowskim prawie religijnym $^{26}$. Z mojej perspektywy ważniejszy jest jednak wymiar polityczny tego rodzaju praktyk, tzn. rozpoznany nie tylko przez de Leóna, ale przez wiele innych badaczek i badaczy, charakter nekroprzemocy jako praktycznej i performatywnej artykulacji rasizmu, nacjonalizmu, klasizmu, towarzyszącej i wzmacniającej inne rodzaje fizycznej i politycznej przemocy, często będącej materialną manifestacją przemocy strukturalnej ${ }^{27}$. To zwykle ciało wykluczonych, zdewaluowanych, zdehumanizowanych Innych jest jej przedmiotem. Definiuję ją dlatego jako praktykę naznaczania innością i dehumanizacji.

W tekście The Politics of Human Remains at the 'Peripheries of the Holocaust' zaproponowałam, żeby właśnie w ten sposób myśleć o systematycznej i długotrwałej praktyce okradania przez Polaków szczątków ludzkich na terenach byłych obozów zagłady w Bełżcu, Sobiborze i Treblince ${ }^{28}$. Praktyka ta rozwinęła się po ich zamknięciu w czasie wojny i trwała do lat 6o., kiedy w tych miejscach powstały pierwsze upamiętnienia. Zjawisko to było wielokrotnie opisywane w literaturze naukowej i publicystycznej, dlatego nie będę tu szczegółowo rekonstruować znanych dziś detali²9. Wystarczy wspomnieć,

M. Lamm The Jewish Way in Death and Mourning, Jonathan David Publishers, New York 2000.

Zob. np. F. Nudelman John Brown's Body. Slavery, Violence, and the Culture of War, The University of North Carolina Press, Chapel Hill 2004; S. Harrison Dark trophies. Hunting and the Enemy Body in Modern War, Berghahn Books, Oxford-New York 2012.

28 Z. Dziuban The Politics of Human Remains at the 'Peripheries of the Holocaust', "Dapim" 2015 No. 29 (3). University Press, Oxford 2012; M. Rusiniak Obóz zagłady w Treblinka II w pamięci społecznej (1943-89), Neriton, Warszawa 2008; P.P. Reszka Płuczki. Poszukiwacze żydowskiego złota, Warszawa, Wydawnictwo Agora, Warszawa 2019. 
że do repertuaru praktyk reprezentantów i reprezentantek lokalnych polskich społeczności należało rozkopywanie i przekopywanie dołów zsypowych, wyłamywanie złotych zębów ze szczęk, obcinanie trupom głów, przeszukiwanie otworów ciała, wydobytych z dołów zwłok, wynoszenie i wywożenie szczątków ludzkich poza teren byłych obozów. Praktyka ta, która, jak dowodzą badaczki i badacze, miała charakter masowy i może być opisywana w kategoriach znormalizowanej „praktyki społecznej”, performatywnie ustanawiała tożsamość muzeów-cmentarzy, zanim zostały one przekształcone w miejsca pamięci (muzea na terenach tych byłych obozów zagłady zostały otwarte stosunkowo późno - w 2004 w Bełżcu, w 1993 w Sobiborze, w 2010 roku w Treblince, dlatego kategorii muzeum-cmentarza używam tu w dużym stopniu umownie).

Kiedy konceptualizowałam okradanie zmarłych i ich "grobów" jako modalność polityki martwych ciał czy, jak proponuję tu, nekroprzemoc, zależało mi na tym, żeby krytycznie spojrzeć na istniejące, dominujące i moim zdaniem problematyczne opisy i konceptualizacje tej praktyki jako formy szabru $^{30}$ czy "gorączki złota" ${ }^{31}$. Ujęcia te, naturalizując chciwość i wyłącznie w jej kategoriach wyjaśniając okradanie zmarłych, wymazują wymiar polityczny tej praktyki, naruszającej ontologiczną dystynkcję między przedmiotem i (martwym) podmiotem, który staje się podmiotem/przedmiotem radykalnego uprzedmiotowienia. Co więcej, fetyszyzując wojenną i powojenną demoralizację oraz biedę jako najważniejszy (jeśli nie jedyny) strukturalny kontekst okradania zmarłych, badacze i badaczki nie tylko znajdują dla tej praktyki usprawiedliwienie, ale znów zacierają jej polityczny wymiar jako formy przemocy popełnianej na zmarłych i jako praktycznej artykulacji antysemityzmu. W polskich badaniach nad Zagładą moim zdaniem ta modalność przemocy jest nadal przemocą epistemologicznie, etycznie i politycznie nierozpoznaną (misrecognized): uniewidzialnioną i nieuznaną ${ }^{32}$. Taką też była z perspektywy kulturowego i politycznego porządku, w którym była popełniana. Zgodnie z definicją de Leóna wystarczy jednak, że to ofiary lub ich grupa kulturowa uznają taką formę obchodzenia się ze szczątkami

M. Zaremba Wielka Trwoga. Polska 1944-1947. Ludowa reakcja na kryzys, Znak, Kraków 2012, s. 225-306.

31 M. Rusiniak Obóz zagłady w Treblinka II, s. 29-39. D. Lis Wokół „Złotych żniw”. Debata o ksiq̨żce Jana Tomasza Grossa i Ireny Grudzińskiej-Gross, Znak, Kraków 2011.

N. Scheper-Hughes, P. Bourgois Introduction, s. 8. 
ludzkimi za „obraźliwą, świętokradczą lub nieludzką", by została ona uznana za nekroprzemoc. Odhaczone ${ }^{33}$.

Przywrócenie tej formie przemocy statusu przemocy i ulokowanie jej w konceptualnej ramie kontinuum przemocy, pozwala także inaczej pomyśleć o jej (infra)strukturalnej podbudowie i artykulacjach. Bardzo prawdopodobne, że proces okradania zmarłych nie rozwinąłby się, gdyby nie nazistowskie ludobójstwo, gdyby nie to, że obozy zagłady powstały obok polskich wsi i miast, gdyby naziści nie wprowadzili praktyki palenia i ukrywania zwłok, żeby zataić ślady swoich zbrodni. Odwołanie do tych materialnych warunków nie wystarczy jednak jako wyjaśnienie i znów prowadzi do odpolitycznienia nekroprzemocy i przestrzeni, w których do niej dochodzi. Ramą kulturową i polityczną, w której można umieścić praktykę okradania zmarłych i bezczeszczenia ich zwłok, stanowi przedwojenny, wojenny i powojenny antysemityzm, dyskryminacja, othering i wykluczenie Żydów z ciała politycznego. Warunkiem możliwości tej praktyki było jednak także to, że do lat 6o. miejsca po byłych obozach nie zostały skutecznie oznaczone i upamiętnione, co, znów, motywowane było faktem, że inaczej niż Auschwitz-Birkenau czy Majdanek, były one przedmiotem żydowskiej, a nie polskiej martyrologii ${ }^{34}$. Kiedy osoby okradające groby stawały przed sądem lub rozmawiały z badaczami i badaczkami, ten brak upamiętnienia i oznaczenia często przywoływany był jako odgórna legitymizacja czy forma przyzwolenia dla praktyki - także sądy uznawały ją za formę usprawiedliwienia ${ }^{35}$. Takie tłumaczenia należy traktować z dużym dystansem, zwracają one jednak uwagę na miejsce, jakie poobozowe krajobrazy zajmowały w porządku ważności suwerennej władzy.To specyficzne usytuowanie wprost przekładało się na ich funkcjonowanie jako politycznie produktywnej infrastruktury, w której zmarli stawali się przedmiotem praktycznej dehumanizacji i odpodmiotowienia. Ten brak upamiętnienia i oznaczenia można interpretować także w kategoriach zarządzania i przemocy, która operuje przez unieważnienie pewnych kategorii martwych podmiotów. Jest to przemoc przez zaniechanie/porzucenie (violence of abandonement).

Dwa najbardziej poruszające przykłady potępienia tej praktyki jako przemocy z perspektywy żydowskiej to teksty Racheli Auerbach i Mordechaja Canina. R. Auerbach Treblinka. Reportaż, w: Wokół "Złotych żniw”...; M. Canin Przez ruiny i zgliszcza. Podróż po stu zgładzonych gminach żydowskich w Polsce, przeł. M. Adamczyk-Grabowska, Nisza, Warszawa 2018. nych i zagłady 1944-1950, Trio, Warszawa 2009, s. 270-272. 
Pisząc o przemocy przez zaniechanie/porzucenie, która obejmuje swoim zasięgiem zarówno życie, jak i śmierć i jej materialne rezultaty, ludzkie ciała, Graham Denyer Willis przywołuje przykład potter's field - nieoficjalnego cmentarza dla ubogich oraz dla wszystkich tych usytuowanych na dnie hierarchii społecznej lub wprost wykluczonych ze wspólnoty. Denyer Willis, opisując Hart Island w Nowym Yorku, rozciąga tę kategorię także na miejsca ukrytych pochówków ofiar zorganizowanej przemocy we współczesnej neoliberalnej Brazylii. Potter's field to zaniedbana przestrzeń ulokowana poza zasięgiem społecznego spojrzenia, to praktyka grzebania zwłok w masowych grobach i „rodzaj ciał w przestrzeni” - ciał ludzi pozbawionych wartości, zarówno za życia, jak i po śmierci, „porzuconych i zdewaluowanych”36. Ukryte tam ciała to ciała ludzi, którzy „, tak by umarli”, ,umarli na własne życzenie” lub „zasłużyli na to, żeby się nawzajem pozabijać” ${ }^{37}$. Potter's field to „cmentarz, który nie jest cmentarzem" ${ }^{\prime 38}$, ponieważ zamiast rehumanizować martwe ciała przyczynia się do ich dalszej dehumanizacji przez to, gdzie zostają pochowane (nieoznaczony masowy grób) i jakim praktykom są poddawane po śmierci.

Interpretuję potters field Denyera Willisa w kategoriach specyficznej infrastruktury będącej materialną artykulacją hierarchii i norm społecznych oraz przemocy strukturalnej. Zaniedbanie/porzucenie jest jedną z podstawowych form działania tej ostatniej, która na poziomie kultury wycofuje pewne formy życia spod obowiązywania troski, następnie przenosi to na ich martwe ciała, otwierając wreszcie przestrzeń dla nekroprzemocowych praktyk, takich jak okradanie zmarłych. Odpowiedzialność za dotykającą je nekroprzemoc zostaje przerzucona na innych aktorów i aktorki lub zostaje zupełnie unieważniona - jak żywi, tak i martwi zdani są na siebie. Takie rozumienie nie-cmentarza wytwarzanego przez zaniedbanie znajduje punkt wspólny z zaproponowanym przez de Leóna opisem modalności nekroprzemocy, do jakiej dochodzi na pograniczu Meksyku i Stanów Zjednoczonych: na pustyni, gdzie umierają nieudokumentowane [undocumented] migrantki i migranci i gdzie pozostawiane są ich ciała, przemoc ta nie ma bezpośredniego charakteru i nie przyjmuje formy ludzkiej ingerencji, delegowana jest raczej na

36 G. Denyer Willis The potter's field, "Comparative Studies in Society and History” 2018 No. 60 (3), S. 539, 540 .

W obu przypadkach mamy do czynienia z zaniechaniem przez państwo wzięcia odpowiedzialności za post mortem życie swoich obywatelek i obywateli. G. Denyer Willis The potter's field, s. 558-563. 
samą pustynną przestrzeń, na wysokie temperatury, na zwierzęta i naturę. To pozorne oddanie ciał naturze jest zdaniem de Leóna praktyką polityczną i formą nekroprzemocy „reprezentującą wartość, jaką przypisuje się życiu i śmierci nieudokumentowanych [undocumented] ludzi" ${ }^{39}$.

W tym właśnie kontekście rozważania Denyera Willisa i de Leóna stają się ważne w myśleniu o przestrzeniach byłych obozów zagłady jako infrastrukturach wytwarzanych przez zaniechanie/porzucenie. Także tu brak ingerencji władzy ma swoje materialne i przestrzenne rezultaty w postaci odpodmiotowionych i zdehumanizowanych martwych ciał (przecież ktoś inny te osoby zabił, spalił i zakopał). Także tu bezpośrednia przemoc zostaje delegowana na naturę, na zwierzęta, na powietrze i wodę - procesy naturalnej ekshumacji wydobywają skremowane szczątki na powierzchnię, dzięki czemu są one nieustannie rozpraszane. Pośrednio, i z pewnością niezgodnie z intencją władzy (ale właśnie przez jej zaniechanie), brak przestrzennej ingerencji otwiera przestrzeń dla nielegalnych praktyk obchodzenia się z martwym ciałem. Nie będę jeszcze raz cytować definicji de Leóna, zgodnie z którą także zaniechanie godnego pochówku interpretowane może być (przez ofiarę i jej grupę kulturową) jako forma nekroprzemocy. Przywołam za to słowa żydowskiego publicysty Mordechaja Canina, napisane między 1946-1947 rokiem. Canin w bardzo podobny do obu przywoływanych badaczy sposób myślał nie tylko o praktyce okradania zmarłych, ale również o nieoznaczeniu i nieupamiętnieniu byłych obozów zagłady: „Do tej pory nikomu nie przyszło do głowy postawić w tym miejscu macewę, zostawić jakiś znak - bo to jest Sobibór, bo tu zginęli tylko Żydzi [...]. Może kiedy człowiek stanie się lepszy, kiedy Żyd dla nie-Żyda zacznie być w pełni człowiekiem, może wtedy ktoś postawi macewę na ogromnym sobiborskim ołtarzu ofiarnym, położy może jakieś kwiaty, a w Zaduszki zapali świeczki, to jak to zgodnie ze zwyczajem robi się w Polsce na grobach męczenników i bohaterów - nie-Żydów..." ${ }^{40}$.

\section{(Nie)ludzkie tafonomie}

Przekształcenie terenów po byłych obozach w oznaczone i zabezpieczone miejsca pamięci to nie tylko symboliczny proces, ale także seria materialnych praktyk i przestrzennych operacji. Również te operacje, takie jak ustalanie i wyznaczanie granic dołów zsypowych, pokrywanie ich kamiennymi płytami lub betonem,

39 J. de León The Land of Open Graves..., s. 72. 
ramowanie przez pomniki - i idąca za tym redefinicja ich jako "grobów" - mają politycznie produktywny charakter. O politycznej produktywności cmentarza jako społecznej i przestrzennej infrastruktury pisze Kevin Lewis O'Neill, przypominając, że cmentarz nie jest jedynie repozytorium ludzkich szczątków. Jest sposobem ustanawiania na nowo relacji między państwem i jego obywatelami i obywatelkami, która (re)definiuje polityczną podmiotowość zmarłych.

Nie jest tak, że cmentarz po prostu łapie zmarłych; cmentarz bierze raczej udział w ustanawianiu, co to znaczy być umarłym. [...] [C]mentarz jako infrastruktura rozciąga rodzaj podmiotowości na zwłoki, i z tą podmiotowością wytwarza cały wachlarz potencjalności. ${ }^{41}$

Przywołane tu „potencjalności” wykraczają poza ponowne włączenie do wspólnoty poprzez materialną dystrybucję w przestrzeni cmentarza, wskazują raczej na wielość praktyk i procesów, poprzez które zmarli znów lokowani są na różnych pozycjach w społecznej hierarchii, dewaluowani czy wykluczani. O’Neill pisze w tym kontekście o zniewadze i zranieniu, którym podlegać mogą szczątki, zarówno jako ciała w sensie materialnym, jak i zmaterializowane polityczne podmioty. Przykładem, który przywołuje, jest praktyka ekshumowania ciał z miejsc ich pierwotnego pochówku i przerzucania do masowych, nieoznaczonych grobów we współczesnej Gwatemali ${ }^{42}$.

Mimo że opisywana przez O'Neilla rzeczywistość jest strukturalnie odmienna od procesów zachodzących od lat 6o. na terenie polskich muzeów-cmentarzy ustanowionych w byłych obozach zagłady, jego rozważania pozwalają wprowadzić w pole widzenia nie tylko potencjalną nekroprzemocowość infrastruktury cmentarza. Zwracają także uwagę na procesualność i dynamikę tej infrastruktury, ustanawianą przez wielość przestrzennych i materialnych praktyk wokół martwych ciał, w których polityczna podmiotowość ludzkich szczątków jest stale redefiniowana i negocjowana. To wyjście poza wizję cmentarza jako hegemonicznie domkniętego "miejsca spoczynku", ku procesom, które to domknięcie poprzedzają, które po nim następują i je destabilizują. Nazywam je tu tafonomiami muzeum-cmentarza.

41 K. Lewis O'Neill There is no more room: Cemeteries, personhood, and bare death, "Ethnography" 2012 No. $13(4)$, s. 517. wspólnoty i, czerpiąc z Giorgio Agambena, wytwarzania "nagiej śmierci”, w której zmarli są zredukowani do statusu „śmieci”. K. O'Neill There is no more room..., s. 517. 
Kategoria tafonomii odgrywa istotną rolę w perspektywie środowiskowej historii Zagłady, gdzie związane z nią masowe groby na terenach poobozowych czytane są jako procesualne podziemne krajobrazy - wytwarzane przez spotkania i wymianę między różnymi, ludzkimi i nieludzkimi formami życia ${ }^{43}$. Tafonomia to nauka o pośmiertnych procesach, jakim podlega ludzkie ciało, procesach dekompozycji, interakcjach, w jakie wchodzi ono z glebą, przyrodą, wodą czy zwierzętami. Dostarcza ona posthumanistycznym badaczkom i badaczom narzędzi do opisu złożonych naturalnych procesów, którym podlegają martwe ciała, włączane tu do „wielogatunkowej wspólnoty [...] różnych form organicznego [...] i nieorganicznego istnienia"44. Moim celem nie jest kwestionowanie tej perspektywy, ale przywrócenie kategorii tafonomii politycznego wymiaru jako narzędzia opisu materialnych praktyk włączania/wyłączania szczątków ludzkich (jak wiemy od de Leóna, także natura i jej procesy zaprzęgnięte mogą zostać do pracy w imię nekroprzemocy). Za de Leónem i Shannon Lee Dawdy myślę o niej jako procesie, który jest równocześnie naturalny i społeczny ${ }^{45}$, obejmując swoim zasięgiem zarówno okradanie grobów, badania archeologiczne czy prace nad upamiętnianiem. Uznanie ich za procesy tafonomiczne sprawia, że wizja muzeum-cmentarza staje się dynamiczna. Pozwala wskazać na wielość często niewidzialnych lub „nieuwidzialnionych” operacji konstytuujących jego tożsamość (i podmiotowość leżących w jego ramach szczątków) oraz zapytać o miejsce tych operacji w kontinuum przemocy - stąd (nie)ludzkie, czyli nekroprzemocowe, tafonomie.

Ze względu na ekonomię tekstu nie mogę sobie pozwolić na szczegółową rekonstrukcję wszystkich od-ludzkich tafonomicznych procesów zachodzących na upamiętnionych terenach byłych obozów zagłady. W innym miejscu rekonstruowałam powojenną chronologię Bełżca i Sobiboru ${ }^{46}$. Także

E. Domańska Nekros. Wprowadzenie do ontologii martwego ciała, PWN, Warszawa 2017, s. 203-206.

Tamże, s. 202. które jako kategorie z nauk przyrodniczych pozwalają moim zdaniem reprezentantkom i reprezentantom nauk humanistycznych pozbawić swoje badania (politycznie) krytycznego ostrza. S. Lee Dawdy The taphonomy of disaster and the (re)formation of New Orleans , "American Anthropologists" 2006 No. 108 (4); J. de León The Land of Open Graves..., S. 72-73.

46 Z. Dziuban Polish sites of memory at the sites of extermination: The politics of framing, w: Space and the Memories of Violence: Landscapes of Erasure, Disappearance and Exception, ed. by E. Schindel, P. Colombo, Palgrave, New York 2014. 
historia miejsca pamięci i muzeum w Treblince jest dobrze rozpoznana ${ }^{47}$. Wszystkie miejsca, upamiętnione po raz pierwszy w latach 6o. - kiedy żydowska tożsamość ich ofiar została niemal całkowicie wymazana ${ }^{48}$ - stały się przedmiotem przebudowy i przewartościowania po 1989 roku. Dziś stoją na nich muzea, opowiadające historię Zagłady Żydów (wystawa w nowo wybudowanym muzeum w Sobiborze nadal czeka na otwarcie). Wszystkie były przedmiotem różnie zakrojonych badań archeologicznych: Bełżec w latach 1997 - 2000, Sobibór w 2000 - 2017, Treblinka 2010 - do dzisis ${ }^{4}$. Każdy z momentów, w których muzea-cmentarze podlegały przekształceniu, otworzył „wachlarz potencjalności" związanych z podatnością szczątków ludzkich na przemoc. Przywołując jeden przykład ulokowany w przestrzeni Sobiboru, pokażę tu krótko, jak nekroprzemoc może się aktualizować.

Jest rok 1963, trwają prace na budową pierwszego upamiętnienia na terenie obozu. Konstruowany jest m.in. kopiec, w którym składane mają być odkryte na miejscu prochy ofiar. Okazuje się jednak, że nie wszystkie szczątki zostały przez nazistów skremowane: kierowca wykorzystywanego do pracy nad kopcem spychacza odsłania kości ludzkie. Na miejsce wezwany zostaje sędzia, wysłany z Warszawy przez Główną Komisję Badania Zbrodni Hitlerowskich w Polsce. Kiedy M. Barciszewski przyjeżdża do Sobiboru, szczątki nie leżą już na powierzchni, zostały przysypane ziemią. Przytoczę tu dużą część jego raportu:

Zgodnie z decyzją miejscowych czynników, miejsce, w którym znaleziono kości przysypano, zwłaszcza, że wydzielał się z stamtąd przykry odór, uniemożliwiający pracę [odór na pewno nie pochodził od nieorganicznych szkieletów, tylko wskazywał na obecność pod powierzchnią materiału organicznego, czyli ciał zmumifikowanych lub w stanie rozkładu przyp. Z.D.]. Na marginesie należy zaznaczyć, że Główna Komisja po uzyskaniu wiadomości o tym poprzez Radę Pomników, wydała polecenie telefoniczne kontynuowania dalszych robót. Jak już wspomniałem w dniu

47 M. Rusiniak Obózzagłady Treblinka ll; E. Kopówka Co wiemyo Treblince. Stan badań, Muzeum Regionalne w Siedlcach, Siedlce 2013; E. Kopówka Treblinka. Historia i pamięć, Muzeum Regionalne w Siedlcach, Siedlce 2015.

48 Żydowskie ciała zostały nie tyle włączone do narodowej wspólnoty, co przez tę wspólnotę przejęte czy przywłaszczone.

49 I. Gilead, Y. Haimi, W. Mazurek Excavating Nazi Extermination Centers, "Present Pasts” 2009 No. 1; C. Sturdy Colls $O$ tym, co minęło, lecz nie zostało zapomniane. Badania archeologiczne na terenie byłego obozu Zagłady w Treblince, przeł. E. Felska, J. Giebułtowski, "Zagłada Żydów” 2012 nr 8. 
mego przybycia miejsce było przysypane i nie miałem technicznych możliwości dokonania bliższych oględzin. [...]

Na podstawie ogólnej znajomości materiałów będących z posiadaniu Głównej Komisji, dotyczących obozu w Sobiborze i po przeprowadzeniu wizji terenu w towarzystwie jednego z miejscowych robotników leśnych, który posiadał informacje o obozie od miejscowej ludności, doszedłem do przekonania, że w terenie tym znajduje się wiele miejsc, w których mieszczą się bądź prochy po spalonych szczątkach (część z nich wydobyto na zewnątrz) bądź szkielety, lecz z uwagi na wiadomy charakter zagłady tegoż obozu, nie sądzę, by było celowe dokonywanie ekshumacji tych szczątków i złożenie ich np. pod usypanym kopcem, gdyż wymagałoby to dłuższego okresu czasu dla przekopania tego terenu i wydobycia, a następnie przeniesienia szczątków w jedno miejsce, a nadto pociągnęłoby to za sobą duże koszty, nie mówiąc już o przedłużeniu prac i uniemożliwieniu zakończenia ich w przewidzianym terminie.

Poza zwiększeniem kosztów związanych z upamiętnieniem tego miejsca, nie dałoby to praktycznych efektów, gdyż już obecnie, w oparciu o posiadane materiały dowodowe, wiadomą jest rzeczą w jaki sposób mordowano ofiary i ile ich tam w przybliżeniu zginęło. [...]

Poinformowano mnie [informacja pochodziła od kierownika Wydziału Kultury we Włodawie - przyp.Z.D.], że miejscowa ludność obecnie kopie miejsca, w których mogą się znajdować prochy, w poszukiwaniu złota. Czyniono już zasadzki, lecz to nie pomaga [...]. Proszono mnie, by zgłosić o tych faktach Radzie Ochrony Pomników w celu zapobieżenia na przyszłość profanacji tego miejsca. Zdaniem ich byłoby wskazane, aby teren okalający przyszły kopiec zalać płytą z cementu. Moim zdaniem byłaby to kosztowana inwestycja [...].50

Wyjeżdżając wydałem polecenie w Wydziale Kultury we Włodawie, aby nie wstrzymywano prac w przypadku dalszego odnalezienia szczątków, lecz miejsce to przysypano. ${ }^{51}$

Decyzję o pokryciu betonowymi płytami miejsc zidentyfikowanych jako masowe groby - motywowaną dokładnie tymi samymi względami, tym, że miejsce jest nadal bezczeszczone przez miejscową ludność - podjęto w Treblince. H. Białczyński Jak powstał pomnik upamiętniający Zagładę Żydów w Treblince. Raport Henryka Białczyńskiego byłego wiceprzewodniczącego Warszawskiej Wojewódzkiej Rady Narodowej, Archiwum ŻıH, Dział Dokumentacji Zabytków, s. 7.

51 Sprawozdanie z wizytacji przeprowadzonej w dniu 27 czerwca 1963 roku. w b. Obozie zagłady w Sobiborze. Archiwum Rady Ochrony Walk i Męczeństwa, 52/4, s.1-3 (dziś w posiadaniu Instytutu Pamięci Narodowej). 
Zarządzenie decydenta z Warszawy poskutkowało tym, że w latach 6o. nie podjęto żadnych prac mających na celu zabezpieczenie znacznej części szczątków zamordowanych w obozie Żydów - oznaczało to, w istocie, ich wyłączenie z politycznej i symbolicznej przestrzeni cmentarza. (W porządku natury pozostają one oczywiście jego częścią). Zrezygnowano z ekshumacji, nie starano się nawet zlokalizować porozrzucanych w przestrzeni byłego obozu dołów zsypowych. Jest to decyzja o tyle interesująca, że podejmowana w kontekście, w którym infrastruktura przyszłego muzeum-cmentarza nadal wytwarzana jest, jak czytamy, przez formy nekroprzemocy (i procesy tafonomiczne) związane z praktyką okradania zmarłych i nekroprzemocą przez zaniechanie/porzucenie. Ta nowa polityka wobec ludzkich szczątków może być odczytywana jako strukturalna kontynuacja drugiej z powyższych modalności nekroprzemocy. A jednak fakt, że utrwalona zostaje w momencie, w którym teren byłego obozu zostaje przekształcony w miejsce „symbolicznego" pochówku, komplikuje taką lekturę. Jest to, jakby nie było, proces aktywnej, przestrzennej i materialnej (re)artykulacji relacji między państwem a jego obywatelami i obywatelkami, którego zakończeniu przypisuje się tu niekwestionowaną wartość. Chociaż przy lekturze „Sprawozdania” nasuwa się pytanie, co jest ważniejsze - upamiętnienie czy jego jak najszybsze, terminowe domknięcie (i hegemoniczne zamknięcie).

Porządek ekonomiczny prioretyzowany jest tu wobec porządku troski wobec zmarłych, przywracania śmierci i jej materialnym rezultatom godności, podmiotowości trupom. Temporalny reżim narzucony przez „planowe” zakończenie prac nad miejscem pamięci okazuje się ważniejszy niż martwe ciała, które powinny być w jego centrum i które leżą tam nieupamiętnione i niezabezpieczone od prawie dwóch dekad. Podobna logika wpisana jest w priorytetyzację porządku wiedzy, w ramach którego szczątki ludzkie zredukowane są do materiału dowodowego, bezużytecznego „z uwagi na wiadomy charakter zagłady tegoż obozu", w którym ginęli tylko Żydzi. Szczątki podlegają tu wielopoziomowemu uprzedmiotowieniu, które blokuje ich niepokojący i destabilizujący charakter jako lu d z k i c h szczątków, zarówno na poziomie politycznym, jak i materialnym. Stają się przez to, znów, podatne na różne formy fizycznego zranienia - przez nielegalną praktykę okradania grobów (która ostatecznie nie zostanie zatrzymana przez zalanie terenu betonem - inwestycja okazała się zbyt kosztowna). Ale także przez działania nieprzygotowanych na kontakt z ludzkimi szczątkami robotników pracujących nad upamiętnieniem, odsłaniających je spychaczem i naruszających ich materialną integralność. W pewnych sensie te formy zranienia zostają 
zmaterializowane za sprawą samej praktyki upamiętnienia i zobiektywizowane w przestrzennej organizacji nowego muzeum-cmentarza. Jako seria infrastrukturalnych i materialnych operacji muzeum-cmentarz staje się tym samym narzędziem reprodukcji i wytwarzania nowych form nekroprzemocy - no exit z kontinuum przemocy.

Wiele z tafonomicznych procesów, które są tej przemocy aktualizacją, pozostaje niewidocznych dla osób odwiedzających hegemonicznie domknięte miejsce pamięci. Jest tak z pracami nad pierwszym upamiętnieniem czy z późniejszym, stosowanym podczas badań archeologicznych, lokowaniem dołów zsypowych poprzez inwazyjne odwierty - wydobywające spod ziemi wyrwane i zdekontekstualizowane fragmenty ludzkich szczątków, znów naruszając ich materialną integralnośćc5. Praktyki te stanowią materialną podbudowę muzeum-cmentarza, ustanawiają jego tożsamość jako nośnika (infra)strukturalnej przemocy. Dlatego właśnie śledzenie procesów, które doprowadziły do jego powstania i zostały użyte do jego redefinicji (badania archeologiczne), dotykając post mortem ludzkich szczątków, jest formą krytycznej tafonomii. Jej celem jest epistemologiczne, etyczne i polityczne uwidzialnienie i uwrażliwianie na modalności nekroprzemocy, ponieważ tylko wtedy, kiedy zostanie ona zidentyfikowana jako przemoc, będzie można położyć jej kres.

52 Taką metodę stosowano w Bełżcu i Sobiborze, zlokalizowane szczątki nie były poddawane ekshumacji. Warto podkreślić, że każda inwazyjna ingerencja archeologiczna (odwierty, a także ekshumacje) jest niezgodna z żydowskim prawem religijnym. 


\section{Abstract}

\section{Zuzanna Dziuban}

INSTITUTE OF CULTURE STUDIES AND THEATRE HISTORY OFTHE AUSTRIAN ACADEMY OF SCIENCES

The Museum-Cemetery: Some Notes on (Infra)Structural Violence

Examining Polish sites of memory and museums established on the grounds of former Nazi death camps, Dziuban proposes that practices dealing with human remains ought to be reconceptualised in terms of necroviolence: violence against human remains. The museum-cemetery is defined here as a politically productive infrastructure that instantiates a material articulation of hierarchies and social norms as well as structural violence in which human remains become objects of subjectification/desubjectification, dehumanisation and exclusion. Analysing the postwar history of Polish sites of memory dedicated to the Holocaust and the practices and infrastructural transformations that arise around them - practices and transformations that include grave robbery, archaeological research and work on commemoration - Dziuban discusses different forms of necroviolence that affect dead bodies as forms of subjectivity susceptible to violence, from immediate physical violence to the violence of abandonment.

\section{Keywords}

(infra)structural violence, necroviolence, human remains, museum-cemetery, Holocaust 